\title{
Model Pembelajaran Think Pair Share (TPS) Untuk Meningkatan Prestasi Belajar Mata Pelajaran IPS Kelas I
}

\author{
Dwi Astuti
}

Guru SDN 1 Pogalan Trenggalek

Email: dwiastuti756@ymail.com

\section{Tersedia Online di \\ http://www.jurnal.unublitar.ac.id/ index.php/briliant}

\begin{tabular}{l}
\hline Sejarah Artikel \\
\hline Diterima pada 29 Juni 2017 \\
Disetuji pada 10 Juli 2017 \\
Dipublikasikan pada: 2 Agustus \\
2017 Hal 328-334
\end{tabular}

Kata Kunci:

think pair share, model, prestasi belajar

\begin{abstract}
Abstrak: Mata pelajaran Ilmu Pengetahuan Sosial (IPS) seringkali dianggap sulit sehingga banyak siswa yang kurang memahami dan mencapai nilai relatif rendah. Kesulitan disebabkan materi yang cukup luas, selalu berkembang, metode ceramah yang digunakan pendidik dan cara belajar siswa yang kurang tepat. Tujuan dalam penelitian ini untuk mengetahui peningkatan prestasi belajar IPS Materi Kasih Sayang melalui model pembelajaran Think Pair Share (TPS) bagi siswa kelas I semester 1 tahun pelajaran 2015/2016 di SDN 1 Pogalan Kecamatan Pogalan Kabupaten Trenggalek. Penelitian tindakan kelas ini merupakan kegiatan yang sangat vital dan merupakan dasar yang dipergunakan untuk merubah pola pikir guru dalam melaksanakan pembelajaran.
\end{abstract}

Pendidikan Nasional berfungsi mengembangkan kemampuan dan membentuk watak serta peradaban bangsa yang bermartabat dalam rangka mencerdaskan kehidupan bangsa, bertujuan untuk berkembangnya potensi peserta didik agar menjadi manusia yang beriman dan bertaqwa kepada Tuhan Yang Maha Esa, berakhlaq mulia, sehat, berilmu, cakap, kreatif, mandiri, dan menjadi warga negara yang demokratis serta bertanggung jawab. Prestasi belajar sebagai kata yang kita dengar dalam dunia pendidikan sebenarnya berasal dari 2 (dua) kata yang digabungkan, yaitu prestasi dan belajar. Dalam Kamus Bahasa Indonesa, pengertian kata prestasi adalah Prestasi menurut Kamus Lengkap Bahasa Indonesia adalah hasil baik yang dicapai (Em Zul Fajri, 2008:670).

Prestasi adalah hasil yang telah dicapai (dari yang telah dilakukan, dikerjakan, dan sebagainya), (Moeliono, 2000:700). Belajar dikatakan pemerolehan pengalaman baru oleh seseorang dalam bentuk perubahan perilaku yang relatif menetap, sebagai akibat adanya proses dalam bentuk interaksi belajar terhadap suatu objek (pengetahuan), atau menilai suatu penguatan (reinforcement) dalam bentuk pengalaman terhadap suatu objek yang ada dalam lingkungan belajar. Pemahaman lain belajar merupakan pemerolehan pengalaman baru, berbentuk perubahan yang relative menetap. Dan hasil belajar dikatakan perubahan yang sifatnya relative menetap, bertahan untuk jangka waktu yang lama. Perubahan yang sifatnya sementara dan tidak dilakukan secara sadar dengan tidak adanya tujuan yang ingin dicapai dalam kegiatan belajar, bukanlah hasil belajar. Belajar terjadi dalam bentuk interaksi. Interaksi dalam kegiatan belajar disebut dengan interaksi belajar mengajar. Pada interaksi tersebut diharapkan 
tercipta stimulus dan respon yang kuat, sehingga dapat dicapai pemahaman yang maksimal (Hamzah B. Uno, 2008:15).

Good dan Brophy menyatakan belajar merupakan suatu proses atau interaksi yang dilakukan seseorang dalam memperoleh sesuatu yang baru dalam bentuk perubahan perilaku sebagai hasil dari pengalaman itu sendiri (Hamzah, 2008:15). Pengalaman belajar akan menghasilkan perubahan sebagai hasil belajar relevan dengan apa yang dipelajari. Belajar merupakan suatu proses kegiatan aktif siswa dalam membangun makna atau pemahaman (Fajar, 2009:10). Belajar dikatakan suatu bentuk pertumbuhan atau perubahan dalam diri seseorang yang dinyatakan dalam cara-cara bertingkah laku yang baru berkat pengalaman dan latihan. Tingkah laku yang baru itu misalnya dari tidak tahu menjadi tahu, timbulnya pengertian baru, serta timbul dan berkembangnya sifat-sifat sosial, susila, dan emosional (Aqib, 2012:42)

Menurut Fathurrohman, ciri-ciri dari kegiatan belajar perubahan yang terjadi berlangsung secara sadar sekurang-kurangnya sadar bahwa pengetahuannya bertambah, sikapnya berubah, kecakapannya berkembang, dan lain-lain; perubahan dalam belajar bersifat continue dan fungsional. Belajar bukan proses yang statis karena terus berkembang secara gradual dan setiap hasil belajar memiliki makna dan guna yang praktis; perubahan belajar bersifat positif dan aktif; perubahan dalam belajar bukan bersifat sementara; perubahan dalam belajar bertujuan dan terarah; dan perubahan mencakup seluruh aspek tingkah laku, bukan bagian-bagian tertentu secara parsial (Fathurrohman, 2010:10)

Kegiatan belajar merupakan kegiatan yang dilakukan untuk menguasai sesuatu, prinsip-prinsip yang dapat membantu tercapainya tujuan dari belajar yakni belajar harus berorientasi pada tujuan yang jelas; proses belajar akan terjadi bila seseorang dihadapkan pada situasi problematic; belajar dengan pemahaman akan lebih bermakna dari pada belajar dengan hafalan; belajar secara menyeluruh akan lebih berhasil dari pada belajar secara berbagi-bagi; belajar memerlukan kemampuan dalam menangkap intisari pelajaran itu sendiri; belajar merupakan proses yang continue; proses belajar memerlukan metode yang tepat; dan belajar memerlukan minat dan perhatian siswa (Fajar, 2009:10-12).

Ilmu Pengetahuan Sosial (IPS) adalah mata pelajaran yang mengkaji kehidupan sosial yang bahannya didasarkan pada bahan kajian sejarah, geografi, ekonomi, sosiologi, antropologi dan tata negara. IPS yang diajarkan di SD terdiri atas dua kajian pokok, pengetahuan sosial dan sejarah mata pelajaran yang memberikan bekal kepada siswa, agar siswa dapat menjadi makhluk sosial yang baik, sehingga dalam kehidupannya dapat diterima dengan baik pula oleh lingkungan masyarakatnya (Dinas Pendidikan Nasional, 2002:159).

Pengajaran Pengetahuan Sosial di SD berfungsi mengambangkan pengetahuan sikap dan ketrampilan dasar untuk memahami kenyataan sosial yang dihadapi siswa dalam kehidupan sehari-hari. Sedangkan pengajaran sejarah berfungsi menumbuhkan rasa kebangsaan, dan bangga terhadap perkembangan masyarakat Indonesia sejak masa lalu hingga masa kini (Dinas Pendidikan dan Kebudayaan, 2002:159). Mengembangkan kemampuan dan sikap rasional siswa dalam menanggapi kenyataan/permasalahan sosial serta perkembangan masyarakat Indonesia maupun masyarakat dunia pada masa lampau, masa kini, dan masa mendatang. Tujuan dari mata pelajaran Ilmu Pengetahuan Sosial di 
Sekolah Dasar bertujuan agar siswa mampu mengembangkan pengetahuan dan ketrampilan dasar yang berguna bagi dirinya dalam kehidupan sehari-hari.

Model Pembelajaran Think Pair Share (TPS) dikembangkan oleh Frank Lyman dan kawan-kawannya dari Universitas Maryland yang mampu mengubah asumsi bahwa metode resitasi dan diskusi perlu diselenggarakan dalam setting kelompok kelas secara keseluruhan. Metode Think Pairs Share memberikan kepada parasiswa waktu untuk berfikir dan merespons serta saling bantu satu sama lain (Nurhadi, 2004:67).

Think Pair Share adalah suatu model pembelajaran kooperatif yang memberi siswa waktu untuk berfikir dan merespon serta saling bantu satu sama lain. Metode ini memperkenalkan ide "waktu berpikir atau waktu tunggu" yang menjadi faktor kuat dalam meningkatkan kemampuan siswa dalam merespons pertanyaan.pembelajaran kooperatif model think pair share ini relatif lebih sederhana karena tidak menyita waktu yang lama untuk mengatur tempat duduk ataupun mengelompokkan siswa. Pembelajaran ini melatih siswa untuk berani berpendapat dan menghargai pendapat teman.

Think Pair Share memiliki prosedur yang secara eksplisit memberi waktu siswa untuk berfikir, menjawab, saling membantu satu sama lain. Dengan demikian, diharapkan siswa mampu bekerja sama, saling membutuhkan, dan saling bergantung pada kelompok kecil secara kooperatif.

Tahap-tahap model pembelajaran Think Pairs Share, tahap satu, think (berpikir). Pada tahap ini guru memberikan pertanyaan yang terkait dengan materi pelajaran. Proses TPS dimulai pada saat ini,yaitu guru mengemukakan pertanyaan yang menggalakkan berpikir ke seluruh kelas.Pertanyaan ini hendaknya berupa pertanyaan terbuka yang memungkinkan dijawab dengan bebagai macam jawaban. Tahap dua, Pairs (berpasangan), pada tahap ini siswa berpikir secara individu. Guru meminta kepada siswa untuk berpasangan dan mulai memikirkan pertanyaan atau masalah yang diberikan guru dalam waktu tertentu. Lamanya waktu ditetapkan berdasarkan pemahaman guru terhadap siswanya, sifat pertanyaannya dan jadwal pembelajaran. Siswa disarankan untuk menulis jawaban atau pemecahan masalah hasil pemikirannya. Dan tahap tiga share (berbagi), pada tahap ini siswa secara individu mewakili kelompok atau berdua maju bersama untuk melaporkan hasil diskusinya ke seluruh kelas.Pada tahap terakhir ini siswa seluruh kelas akan memperoleh keuntungan dalam bentuk mendengarkan berbagai ungkapan mengenai konsep yang sama dinyatakan dengan cara yang berbeda oleh individu yang berbeda (Aris Shoimin, 2014:208).

Peneliti merasa yakin kelebihan diperoleh dari penerapan model pembelajaran think pair share adalah TPS mudah diterapkan di berbagai jenjang pendidikan dan dalam setiap kesempatan; menyediakan waktu berfikir untuk meningkatkan kualitas respons siswa; siswa menjadi lebih aktif dalam berfikir mengenai konsep dalam mata pelajaran; siswa lebih memahami tentang konsep topik pelajaran selama diskusi; siswa dapat belajar dari siswa lain; setiap siswa dalam kelompoknya mempunyai kesempatan untuk berbagi atau menyampaikan idenya.

\section{METODE}

Penelitian ini merupakan penelitian tindakan kelas (PTK), dilakukan untuk memperbaiki kualitas pembelajaran, dengan siklus sebanyak 4 tahapan, 
yakni tahap perencanaan, tahap pelaksanaan (tindakan), tahap pengamatan, dan tahap refleksi. Penelitian dilakukan pada subjek siswa SDN 1 Pogalan Kecamatan Pogalan Kabupaten Trenggalek, khususnya siswa kelas I semester 1 tahun pelajaran 2015/2016, dengan jumlah siswa sebanyak 20 siswa, yang terdiri dari 12 siswa laki-laki dan 8 siswa perempuan. Cara yang ditempuh untuk memperoleh data penelitian mengenai prestasi belajar siswa mata pelajaran IPS, dengan mempergunakan metode observasi dan test. Penelitian berlangsung selama 3 bulan pada Agustus 2015 sampai dengan November 2015.

Isntrumen yang digunakan dalam penelitian ini berupa lembar observasi/pengamatan dan soal tes. Lembar soal test merupakan instrument utama, diberikan siswa tiap akhir pembelajaran untuk mengetahui seberapa jauh keberhasilannya dalam melaksanakan proses pembelajaran. Observasi/pengamatan merupakan instsrument penunjang atau instrument pendukung ini, akan memberikan data tentang prosentase siswa aktif dam siswa pasif. Bentuk penelitian reflektif yang dilakukan oleh guru sendiri hasilnya dapat dimanfaatkan sebagai alat untuk pengembangan kurikulum, pengembangan sekolah, pengembangan keahlian mengajar, dan sebagainya" (Sukidin, 2012:14).

Untuk menganalisis tingkat keberhasilan siswa setelah proses pembelajaran setiapcakhir siklus dilakukan evaluasi berupa soal tes tertulis dengan menggunakan analisis statistic sederhana.

Menghitung hasil test akhir siswa, dengan rumus:

$\mathrm{NA}=$ Jumlah soal dijawab benar $\mathrm{X} 10$

Untuk menentukan nilai rata-rata Pendidikan Kewarganegaraan dianalisis dengan menggunakan rumus :

$$
\begin{aligned}
& \mathrm{Mx}=\frac{\sum X}{N} \\
& \mathrm{Mx}=\text { Rata-rata prestasi IPS } \\
& \sum \mathrm{X}=\text { Jumlah nilai keseluruhan } \\
& \mathrm{N} \quad=\text { Jumlah siswa }
\end{aligned}
$$

Menghitung jumlah siswa aktif dan siswa pasif, dengan ketentuan:

$\begin{array}{ll}\text { Siswa aktif } & =\frac{\text { SiswaAktif }}{\text { JumlahSiswaSeluruhnya }} \times 100 \% \\ \text { Siswa tidak aktif }= & \frac{\text { SiswaTidakAktif }}{\text { JumlahSiswaSeluruhnya }} \times 100 \%\end{array}$

Menghitung prosentase peningkatan ketuntasan belajar dilakukan dengan mencari selisih prosentase ketuntasan pada siklus I dan siklus II.

\section{HASIL}

\section{Pra Siklus}

KKM pada tahap pra siklus ditetapkan sebesar 70 dengan kajian materi yang dibahas sub bab pengalaman bersama saudara. Hasil evaluasi sebelum pembelajaran sesuai metode yang ditentukan didapat siswa tuntas pada tahap pra 
siklus sebanyak 13 siswa dari 20 siswa (65\%). Sedangkan siswa yang tidak tuntas adalah 7 siswa (35\%). Pada tahap pra siklus, modus berada pada nilai kurang dari 70, sebanyak 7 siswa (35\%). NIlai rata-rata kelas sebesar 74. Ditinjau dari keaktifan siswa, sebanyak 9 siswa (45\%) siswa aktif dan 11 siswa (55\%) siswa pasif. Beberapa hal yang dijadikan refleksi dari pelaksanaan pra siklus yaitu guru tidak menggunakan alat peraga, guru tidak mengaktifkan siswa; guru mendominasi kegiatan pembelajaran.

Berdasarkan beberapa hasil refleksi, maka peneliti ingin memperbaiki proses pembelajaran dengan menerapkan model pembelajaran Think Pair Share (TPS) pada siklus I dan siklus II.

\section{Siklus I}

KKM pada tahap siklus I ditetapkan sebesar 70 dengan materi yang dibahas adalah Kasih Sayang Ayah. Tahap penelitian pada siklus I antara lain planning (perencanaan), acting (tindakan), observing (pengamatan), reflecting (refleksi) dan revise plan (perbaikan rencana).

Pertemuan I, tahap perencanaan beberapa hal yang dilakukan menyusun silabus, menyusun RPP, menyusun LKS, menyiapkan media pembelajaran, menyusun lembar pengamatan tentang keaktifan siswa, dan menyusun test akhir. Tahap pelaksanaan disesuaikan dengan langkah-langkah yang ditetapkan pada model pembelajaran Think Pair Share. Langkah-langkahnya guru menjelaskan tujuan pembelajaran yang ingin dicapai, menjelaskan cara menerapkan model pembelajaran TPS, Tanya jawab dengan siswa tentang materi kasih sayang sebagai apersepsi, menyampaikan materi kasih sayang ayah secukupnya, membentuk kelompok siswa secara berpasangan dengan teman sebangkunya, siswa bercakap-cakap dan saling menyampaikan ide tentang kasih sayang ayah dengan teman pasangannya, siswa menyampaikan hasil percakapannya di depan kelas dengan (bisa membaca buku bisa tanpa buku), Guru memberikan pujian kepada siswa, siswa membuat kesimpulan dibantu oleh guru, dan siswa membaca kesimpulan di depan kelas. Tahap pengamatan yang diperoleh menunjukkan sebanyak 10 siswa (50\%) siswa aktif dan 10 siswa (50\%) siswa pasif.

Pertemuan II, tahap perencanaan melakukan penyusunan silabus, penyusunan RPP, penyusunan LKS, penyiapan media pembelajaran, penyusunan lembar pengamatan tentang keaktifan siswa, dan menyusun test akhir. Tahap pelaksanaan langkah-langkah sesuai model Think Pair Share berdasarkan ghasil refleksi pertemuan I. Tahap pengamatan hasil yang diperoleh menunjukkan sebanyak 11 siswa (55\%) siswa aktif dan 9 siswa (45\%) siswa pasif.

\section{Siklus II}

Siklus II dilaksanakan dengan mempertimbangkan hasil refleksi dan perbaikan siklus I. Materi pada siklus II adalah Kasih Sayang Anak KKM yang ditentukan pada materi ini adalah 70. Pertemuan I, tahap perencanaan aktifitas guru menyusun silabus, menyusun skenario pembelajaran, menyusun LKS, menyiapkan media pembelajaran, menyusun lembar pengamatan tentang keaktifan siswa, dan menyusun test akhir. Pelaksanaan tindakan model pembelajaran Think Pair Share (TPS) pada siklus II, pengamatan tentang keaktifan siswa yang dilakukan selama kegiatan inti berlangsung, menunjukan hasil sebanyak 13 siswa (65\%) aktif dan sebanyaj 7 siswa (35\%) siswa pasif. 
Pertemuan II, tahap perencanaan, aktifitas guru menyusun silabus, menyusun skenario pembelajaran, menyusun LKS, menyiapkan media pembelajaran, menyusun lembar pengamatan tentang keaktifan siswa, dan menyusun test akhir. Pelaksanaan tindakan untuk model pembelajaran Think Pair Share (TPS) pada siklus II, dilaksanakan sebagaimana pada siklus I, pengamatan keaktifan siswa yang dilakukan selama kegiatan inti berlangsung, menunjukan hasil sebanyak 15 siswa (75\%) aktif dan sebanyak 5 siswa (25\%) siswa pasif.

\section{PEMBAHASAN}

Pada siklus I analisis tingkat ketuntasan belajar siswa dan segala sesuatu yang berkaitan dengan pelaksanaan pembelajaran didapat simpulan bahwa siswa tuntas sebanyak 15 siswa dari 20 siswa (75\%). Sedangkan siswa yang tidak tuntas 5 siswa (25\%). Pada tahap siklus I, modus berada pada nilai lebih dari cukup (80), sebanyak 6 siswa (30\%), nilai rata-rata kelas naik menjadi 77. Hasil refleksi dari pelaksanaan tahap siklus I siswa masih terlihat sangat canggung dalam menyampaikan ide kepada temannya, hal ini disebabkan karena siswa hanya terbiasa mendengar penjelasan guru dan kurang aktif selama pembelajaran dan cara belajar siswa belum maksimal. Melihat hasil refleksi tersebut, maka penelitian dilakukan kembali pada siklus II dengan harapan siswa dapat mengurangi kecanggungannya dalam menerapkan model pembelajaran TPS, sehingga siswa dapat belajar dengan lebih baik dan diharapkan prestasi belajar siswa dapat meningkat.

Pada siklus II, siswa tuntas sebanyak 17 siswa dari 20 siswa (85\%). Sedangkan siswa yang tidak tuntas adalah 3 siswa (15\%). Pada tahap siklus II, modus berada pada nilai lebih dari cukup (80), sebanyak 6 siswa (30\%), nilai ratarata kelas naik menjadi 82 . Hasil simpulan refleksi dari pelaksanaan tahap siklus II di dapat siswa tidak lagi terlihat sangat canggung dalam menyampaikan ide kepada temannya, kelas terlihat aktif dan saling bertukar informasi dengan sesama teman, dan prestasi belajar siswa meningkat dengan sangat signifikan. Melihat hasil refleksi tersebut, maka proses pembelajaran dengan model Think Pair Share telah sesuai tujuan, sehingga penelitian dihentikan pada siklus II dan pelaksanaan lanjut pembelajaran dengan model Think Pair Share dengan berbagai inovasi yang menarik dan menantang.

Perbandingan hasil belajar siswa pada siklus I dan siklus II, siswa tuntas pada siklus I sebanyak 15 siswa (75\%) dan siswa tuntas pada siklus II adalah 17 siswa (85\%), terjadi kenaikan siswa tuntas sebanyak 2 siswa (10\%), eata-rata kelas pada siklus I adalah 77 dan rata-rata kelas pada siklus II adalah 82. Siswa aktif pada akhir siklus I sebanyak 11 siswa (55\%) dan sebanyak 9 siswa (45\%) pasif. Siswa aktif pada akhir siklus II sebanyak 15 siswa (75\%) dan sebanyak 5 siswa (25\%) pasif, sehingga terdapat kenaikan siswa aktif dari siklus I ke siklus II sebanyak 4 siswa $(20 \%)$

\section{KESIMPULAN}

Berdasarkan hasil penelitian tindakan kelas yang telah dilakukan, maka dapat diambil kesimpulan bahwa siswa tuntas pada siklus I sebanyak 15 siswa (75\%) dan pada siklus II adalah 17 siswa (85\%), terjadi kenaikan siswa tuntas sebanyak 2 siswa (10\%); rata-rata kelas pada siklus I adalah 77 dan pada siklus II adalah 82, telah terjadi kenaikan rata-rata kelas sebesar 5 poin; dan siswa aktif 
pada siklus I sebanyak 11 siswa (55\%) dan pada siklus II sebanyak 15 siswa (75\%), terdapat kenaikan siswa aktif dari siklus I ke siklus II sebanyak 4 siswa (20\%). Sehingga kesimpulan dari penelitian secara keseluruhan telah terjadi peningkatan prestasi belajar IPS Materi Kasih Sayang setelah menerapkan model pembelajaran Think Pair Share (TPS) bagi siswa kelas I semester 1 tahun pelajaran 2015/2016 di SDN 1 Pogalan Kecamatan Pogalan Kabupaten Trenggalek.

\section{SARAN}

Merupakan unsur utama sebagai pelaksana pendidikan, guru diharapkan terus mengadakan pembaharuan, mempunyai semangat untuk berinovasi, sehingga siswa sebagai subjek pendidikan tidak dirugikan. Adanya inovasi dari guru dapat meningkatkan semangat belajar siswa, diantaranya inovasi dalam penerapan model pembelajaran. Siswa sebagai subjek pendidikan hendaknya mempunyai semangat yang tinggi untuk belajar. Dengan semangat yang tinggi diharapkan agar siswa mempunyai daya saing yang tinggi pula, sehingga dapat, menjadi lulusan yang dapat memenuhi tuntutan perkembangan zaman.

\section{DAFTAR RUJUKAN}

Astuti, Pudji, dkk._. Pendidikan Ilmu Sosial. University Press IKIP Surabaya

Aqib, Zainal. 2012. Profesionalisme Guru dalam Pembelajaran. Surabaya: Insan Cendekia

Fajri, Em Zul. 2008. Kamus Lengkap Bahasa Indonesia. Diffa Publisher

Fajar, Arnie. 2009. Portofolio. Bandung: Rosdakarya

Fathurrohman, Pupuh. 2010. Strategi Belajar Mengajar. Bandung: Refika Aditama

Moeliono, 2000. Kamus Besar Bahasa Indonesia. Jakarta:Balai Pustaka.

Nurhadi, 2004. Pembelajaran Kontekstual dan Penerapanya dalam KBK. Malang: Universitas Negeri Malang (UM Press).

2002. Penyesuaian Garis-Garis Besar Program Pengajaran (GBPP)

Sistem Semester Sekolah Dasar. Dinas Pendidikan dan Kebudayaan

Shoimin, Aris. 2014. 68 Model Pembelajaran Inovatif dalam Kurikulum 2013.Yogyakarta:Ar-Ruzz Media.

Uno, Hamzah B. 2008. Teori Motivasi dan Pengukurannya. Jakarta: Bumi Aksara 